\title{
AN Elegy for GREg HaM: COPYRIGHT LAW, THE KOOKABURRA CASE, AND REMIX CULTURE
}

\section{MATTHEW RIMMER*}

The Kookaburra case was a tragic and controversial copyright dispute, highlighting the need for copyright law reform by the Australian Parliament. In this case, a copyright action was brought by Larrikin Records against Men at Work, alleging copyright infringement by Down Under of the Kookaburra song composed by Marion Sinclair. The dispute raised a host of doctrinal matters. There was disquiet over the length of the copyright term. There were fierce contests as to the copyright ownership of the Kookaburra song. The litigation raised questions about copyright infringement and substantiality particularly in relation to musical works. The case highlighted frailties in Australia's regime of copyright exceptions. The litigation should spur the Australian Law Reform Commission to make recommendations for law reform in its inquiry, Copyright and the Digital Economy. This paper provides a critical evaluation of the options of a defence for transformative use; a defence for fair use; and statutory licensing. The paper also examines the question of appropriate remedies in respect of copyright infringement. The conclusion considers the implications of the Kookaburra case for other forms of musical works - including digital sampling, mash-ups, and creative remixes. It finishes with an elegy for Greg Ham - paying tribute to the multiinstrumentalist for Men at Work.

\section{INTRODUCTION}

As a child of the 1980s, I have fond memories of the Australian band Men at Work and their song Down Under, a pub rock anthem. The almanac, The 100 Best Australian Albums by John O’Donnell, Toby Creswell and Craig

\footnotetext{
*BA/LLB ANU, Phd UNSW; Australian Research Council Future Fellow; Associate Professor at the ANU College of Law; Associate Director of the Australian Centre for Intellectual Property in Agriculture (ACIPA). The author would like to thank Dr Dan Meagher for the invitation to participate in the Digital Sampling/ Remix Culture Forum at Deakin Law School.
} 
Mathieson, ${ }^{1}$ ranks Men At Work’s album Business As Usual at 99 in their list. The profile says of the band Men At Work:

The brainchild of Colin Hay, an expatriate Scot who was the principal songwriter, singer and rhythm guitarist, Men at Work was an unlikely collection of personalities - guitarist Ron Strykert, bass player John Rees, drummer Jerry Speiser and Greg Ham on saxophone, keyboards and flute without a conventionally definable genre. Their style was an amalgam of new wave rock and lite reggae with Hay's expressive voice not far removed from the sound of Sting. The songs tended to be paranoid fantasies offset by madcap humour. McIan's production relied on the big, heavily treated drum sound that characterised most '80s pop. There are layers of keyboard atmospherics through which snake Strykert's guitar lines and Ham's saxophone. $^{2}$

The song Down Under became a de facto national anthem during Australia's victory in the America's Cup. ${ }^{3}$ The song (and the album Business as Usual) were a popular and a commercial success: 'With sales of over 15 million copies, Business as Usual demonstrated to both Americans and Australians that it was possible to make international hits on the other side of the equator'. 4 The group released two further albums: Cargo in 1983, and Two Hearts in 1985. The oeuvre of Men at Work has also been the subject of a number of compilation albums as well. The band broke up in 1986. Men at Work reformed in 1996 for a South American Tour. Memorably, Men at Work performed for the Closing Ceremony at the Sydney Olympics in 2000. ${ }^{5}$ The lead singer, Colin Hay, has also pursued an energetic solo career. The work Down Under has been memorialised as a classic Australian anthem. The Australian National Film and Sound Archive has the song Down Under available in various formats: as a sound recording, radio broadcast, television broadcast, and as a film. Down Under is accessible in its gallery as a music video and a sound recording. ${ }^{6}$

On Wednesday 26 September 2007, the ABC broadcast a children's special of its music quiz show on television, Spicks ' $n$ Specks. ${ }^{7}$ The host Adam Hill asked

${ }^{1}$ John O’Donnell, Toby Creswell and Craig Mathieson, The 100 Best Australian Albums (Hardie Grant Books, 2010).

2 Ibid 250.

${ }^{3}$ Ibid.

${ }^{4}$ Ibid.

5 Men at Work, 'Down Under': Sydney 2000 Olympic Games (2012) Daily Motion $<$ http://www.dailymotion.com/video/xfpqkf_men-at-work-down-under-sydney-2000-olympicgames_sport>.

${ }^{6}$ See the National Film and Sound Archive <http://www.nfsa.gov.au/>.

${ }^{7}$ Spicks ' $n$ Specks (ABC Television, 2007) <http://www.youtube.com/watch?v=IT8SHafGIpU>; Steve Collins, 'Kookaburra v Down Under: It's Just Overkill' (2010) 7 (1) Journal of Media Arts Culture <http://scan.net.au/scan/journal/display.php?journal_id=145>. 
teams to 'name the Australian nursery rhyme this riff has been based on' before playing an excerpt from Down Under. The contestant, Jay Laga'aia, answered 'Kookaburra sitting in the old gum tree?'. This incident alerted Larrikin Records to the resemblance between the Kookaburra song and Down Under.

The dispute went through a number of stages. Initially, EMI claimed in 2008 that Larrikin had made unjustifiable threats of copyright infringement within the meaning of s 202 (1) of the Copyright Act 1968 (Cth) on the basis that Down Under did not infringe copyright in Kookaburra. ${ }^{8}$ In response, Larrikin claimed that Down Under infringed copyright as it reproduced a substantial part of Kookaburra and that the EMI parties had authorised infringements by the grant of licences in respect of Down Under, including but not limited to, the Qantas advertisements. ${ }^{9}$ A series of judgments followed. First, in the Federal Court of Australia, there was a determination by Jacobson J in 2009 as to the ownership of the musical work. ${ }^{10}$ Secondly, Jacobson $\mathrm{J}$ ruled as to whether there was an infringement of copyright in the Kookaburra musical work by Men at Work's Down Under. ${ }^{11}$ Thirdly, there was a decision by Jacobson $\mathrm{J}$ as to remedies. ${ }^{12}$ Fourthly, there was an appeal to the Full Court of the Federal Court of Australia, which was rejected in 2011. ${ }^{13}$ Finally, there was an unsuccessful effort to appeal against the ruling to the High Court of Australia in October $2011 .^{14}$

The Kookaburra case should be viewed in light of a longstanding history of conflict and disputation over copyright law and music. ${ }^{15}$ It has been heartening to observe over the past two decades the rise in empirical scholarship and

\footnotetext{
${ }^{8}$ EMI Songs Australia Pty Ltd v Larrikin Music Publishing Pty Ltd, No NSD 340 of 2008.

${ }^{9}$ Larrikin Music Publishing Pty Ltd v EMI Songs Australia Pty Ltd, No NSD 145 of 2008.

${ }^{10}$ Larrikin Music Publishing Pty Ltd v EMI Songs Australia Pty Ltd [2009] FCA 799. This article does not look at this dispute for reasons of space. The conflict over the copyright authorship and ownership of Kookaburra Sits in the Old Gum Tree and Down Under resembles a Pirandello play or a novel by Italo Calvino. There were multiple claims to the musical work of the Kookaburra song by Marion Sinclair, the Girl Guides, the Public Trustee, the Libraries Board of South Australia, and Larrikin Records. Some have argued that Kookaburra is a folk song, which belongs in the public domain. Similarly, there were a diversity of claims of copyright authorship and ownership in respect of Men at Work's song Down Under - including by Men at Work, EMI, and Larrikin Records.

${ }^{11}$ Larrikin Music Publishing Pty Ltd v EMI Songs Australia Pty Ltd [2010] FCA 29 ('Larrikin').

${ }^{12}$ Larrikin Music Publishing Pty Ltd v EMI Songs Australia Pty Ltd (No 2) [2010] FCA 698 ('Larrikin No 2').

${ }^{13}$ EMI Songs Australia Pty Ltd v Larrikin Music Publishing Pty Ltd [2011] FCAFC 47 ('Larrikin Appeal').

${ }^{14}$ Transcript of Proceedings, EMI Songs Australian Pty Ltd v Larrikin Music Publishing Pty Ltd [2011] HCATrans 284 (Gummow and Bell JJ).

${ }^{15}$ For a history of copyright law and music, see Joanna Demers, Steal This Music: How Intellectual Property Law Affects Musical Creativity (University of Georgia Press, 2006).
} 
documentary film-making on copyright law and musical works. Kembrew McLeod and his collaborators have systematically interviewed a wide crosssection of the music industry on copyright law and musical works - for both print and film. ${ }^{16}$ Peter Jaszi and Pat Aufderheide have been writing about how documentary film-makers grapple with copyright law. ${ }^{17}$ There has also been a number of fine documentaries made about copyright law, including Rip!: A Remix Manifesto, ${ }^{18}$ Copyright Criminals, ${ }^{19}$ and Chevolution. ${ }^{20}$ Paul Kelly's musical memoir How to Make Gravy ${ }^{21}$ has been turned into a documentary called Stories of $\mathrm{Me}^{22}$ Even a documentary like Under African Skies about the making of Paul Simon's Graceland has an interesting discourse about copyright law, musical collaboration, cultural appropriation and transformation, and boycotts. $^{23}$

Applying this approach, this article contends that the Kookaburra case highlights the need for substantive copyright law reform - whether under the auspices of the Australian Law Reform Commission (ALRC) ${ }^{24}$ or through future law reform sessions. In Creative License, Kembrew McLeod and Peter DiCola comment in their conclusion about the need for a collective conversation for the reform of copyright law and digital sampling:

As pressure grows on the existing system, we urge policy makers, the creative community, and the public to consider reforms both incremental and daring. We need a combination of initiatives to confront the ways that the law has not caught up with contemporary creative practices - or, for that matter, very old creative practices. Sampling is but one incarnation of the sorts of social exchanges that are defining the experience of being human in the twenty-first century. If we don't address the impasse between samplers and samples, it

${ }^{16}$ Kembrew McLeod and Peter DiCola, Creative License: The Law and Culture of Digital Sampling (Duke University Press, 2011); Benjamin Franzen and Kembrew McLeod, Copyright Criminals (2010) IndiePix Films <http://www.copyrightcriminals.com/>

${ }^{17}$ Patricia Aufderheide and Peter Jaszi, Reclaiming Fair Use: How to Put Balance Back into Copyright (University of Chicago Press, 2011).

${ }^{18}$ Brett Gaylor, RiP!: A Remix Manifesto (2009) Eyesteel Film and the National Film Board of Canada <http://www.nfb.ca/film/rip_a_remix_manifesto/>

${ }^{19}$ Franzen and McLeod, above n 16.

20 Luis Lopez and Trish Ziff, Chevolution (2008) Red Envelope Entertainment $<$ http://www.madman.com.au/catalogue/view/13157/chevolution>.

${ }^{21}$ Paul Kelly, How to Make Gravy (Penguin, 2010).

22 Ian Darling, Stories of Me (2012) Shark Island Productions $<$ http://www.paulkellythemovie.com.au/splash/>.

23 Joe Berlinger, Under African Skies (2012) Radical Media $<$ http://www.imdb.com/title/tt2112868/>.

24 See ALRC, Copyright and Digital Economy (30 May 2012) $<$ http://www.alrc.gov.au/inquiries/copyright-and-digital-economy>. 
will be to everyone's detriment that the law and the practice of everyday life will increasingly diverge. ${ }^{25}$

Part II of this paper examines matters of copyright infringement and substantiality. This section highlights how various interpretative communities have considered the Kookaburra case. Part III explores copyright exceptions, especially in light of the ALRC inquiry into Copyright and the Digital Economy. ${ }^{26}$ It provides a critical evaluation of the options of a defence for transformative use, a defence for fair use, and statutory licensing. Part IV examines the question of appropriate remedies in respect of copyright infringement. The conclusion considers the implications of the Kookaburra case for other forms of musical works, including digital sampling, mash-ups, and creative remixes. It finishes with an elegy for Greg Ham, considering the tributes paid to the musician at his funeral.

\section{COPYRIGHT INFRINGEMENT}

The Kookaburra case also raised larger questions about copyright infringement, and the definition of a 'substantial part' and a 'musical work'. There is a tension between the approach of the judges in the Kookaburra case, and the authority of IceTV Pty Ltd v Nine Network Australia Pty Ltd. ${ }^{27}$ The decision on copyright infringement also highlights divergences in approach from comparative precedents on copyright law, digital sampling, and musical works.

\section{A IceTV}

The 2009 ruling by the High Court of Australia in IceTV is the key precedent in respect of copyright infringement. French CJ, Crennan and Kiefel JJ commented in the case upon the need to consider the higher policy objectives of Australian copyright law:

Copyright legislation strikes a balance of competing interests and competing policy considerations. Relevantly, it is concerned with rewarding authors of original literary works with commercial benefits having regard to the fact that literary works in turn benefit the reading public. In both its title and opening recitals, the Statute of Anne of 1709 echoed explicitly the emphasis on the practical or utilitarian importance that certain seventeenth century philosophers attached to knowledge and its encouragement in the scheme of human progress. The 'social contract' envisaged by the Statute of Anne, and

\footnotetext{
${ }^{25}$ McLeod and DiCola, above n 16, 267-8.

${ }^{26}$ ALRC, above $\mathrm{n} 24$.

${ }^{27}$ IceTV Pty Ltd v Nine Network Australia Pty Ltd [2009] HCA 14 ('IceTV').
} 
still underlying the present Act, was that an author could obtain a monopoly, limited in time, in return for making a work available to the reading public. ${ }^{28}$

This statement is an important guide to the raison d'être of the Australian copyright regime. The High Court emphasised that the original United Kingdom copyright legislation was 'an Act for the encouragement of learning, by vesting the copies of printed books in the authors or purchasers of such copies, during the times therein mentioned' and designed 'for the encouragement of learned men to compose and write useful books'. ${ }^{29}$ The Court also referred to the approaches of the Supreme Court of the United States and the Supreme Court of Canada in articulating the public policy objectives and purposes of copyright law. ${ }^{30}$

French CJ, Crennan and Kiefel JJ emphasised that determinations of copyright infringement need to take into account larger questions of the nature and function of copyright law, and its relationship to the intellectual commons:

Copyright, being an exception to the law's general abhorrence of monopolies, does not confer a monopoly on facts or information because to do so would impede the reading public's access to and use of facts and information. Copyright is not given to reward work distinct from the production of a particular form of expression. These concepts are relevant to the determination, called for by the Act, of whether a part reproduced is a 'substantial part' of a work in which copyright subsists. ${ }^{31}$

The three judges observed: 'In order to assess whether material copied is a substantial part of an original literary work, it is necessary to consider not only the extent of what is copied: the quality of what is copied is critical. ${ }^{32}$ Their Honours emphasised: 'It is often said that questions of whether a substantial part has been copied are questions of fact and degree', ${ }^{33}$ and stressed that 'a factor critical to the assessment of the quality of what is copied is the "originality" of the part which is copied, ${ }^{34}$

In the case of IceTV, the High Court was adamant that the concept of substantiality was a demanding, meaningful standard. Gummow, Hayne and Heydon JJ were highly critical of the approach of the Full Federal Court to the

\footnotetext{
${ }^{28}$ Ibid [24]-[26].

${ }^{29}$ Ibid.

${ }^{30}$ See Feist Publications Inc v Rural Telephone Service Co Inc, 499 US 340 (1991); CCH Canadian Ltd v Law Society of Upper Canada [2004] 1 SCR 339.

${ }^{31}$ IceTV [2009] HCA 14 [28]-[29].

${ }^{32}$ Ibid [30].

${ }^{33}$ Ibid [32].

${ }^{34}$ Ibid [32].
} 
question of substantiality. The judges commented upon the proper approach to the determination of questions of substantiality:

The effect of s 14(1)(a) of the Act is that an infringement by reproduction of a work may result from the reproduction of 'a substantial part of the work'. The word 'substantial' has been said to be 'not only susceptible of ambiguity' but to be 'a word calculated to conceal a lack of precision'. However that may be, which of the various possible shades of meaning the word bears in a provision such as s 14 of the Act will be determined by the context. With respect to s 14, that context includes the matters of development of copyright law to which reference has been made earlier in these reasons. ${ }^{35}$

The judges emphasised that, on the facts of the case, the Full Court approached the issue of substantiality at too high a level of abstraction, and in doing so tipped the balance too far against the interest of viewers of digital free to air television in the dissemination by means of new technology of program listings. ${ }^{36}$ The judges noted: "The Full Court did so by treating the issue of substantiality as dominated by an "interest" in the protection of Nine against perceived competition by Ice. ${ }^{37}$ Furthermore, 'the statutory requirement that the part of a work taken must be substantial assumes there may be some measure of legitimate appropriation of that investment'. ${ }^{38}$

The ruling in IceTV is an important precedent. The High Court emphasised that 'substantiality' is an important and meaningful test for copyright infringement. A 'substantial part' is not a nominal standard satisfied as a matter of course or a mere routine formality.

\section{B The Kookaburra Case}

The Federal Court of Australia has shown little fondness for the practice of digital sampling. ${ }^{39}$ The 2010 Federal Court of Australia decision in Larrikin ${ }^{40}$ raises concerns about the status of mash-ups in Australia. In this matter, Larrikin Records sued EMI and members of Men at Work, alleging that the 1980s pub rock anthem Down Under infringed copyright in the song,

\footnotetext{
${ }^{35}$ Ibid [154].

${ }^{36}$ Ibid [161].

${ }^{37}$ Ibid.

${ }^{38}$ Ibid [157].

${ }^{39}$ See, eg, Universal Music Australia Pty Ltd v Miyamoto [2003] FCA 812; Universal Music Australia Pty Ltd v Miyamoto [2004] FCA 982; Commonwealth Director of Public Prosecutions $v \mathrm{Ng}$, Tran and Le (unreported, Sydney Central Local Court, Henson DCM, 18 November 2003).

${ }^{40}$ Larrikin [2010] FCA 29.
} 
Kookaburra Sits in an Old Gum Tree. Following a formalistic line of reasoning, Jacobson J held that there was indeed infringement:

It is true that Kookaburra is a short work and that it is not reproduced in Down Under as a round. But it was not suggested by the respondents that Kookaburra is so simple or lacking in substantial originality that a note for note reproduction of the entire work was required to meet the 'substantial part' test. Nor could any such submission be sustained. The short answer to the qualitative test is to be found in Mr Hay's performance of the words of Kookaburra to the tune of the flute riff in Down Under. In my opinion, that was a sufficient illustration that the qualitative test is met. The reproduction did not completely correspond to the phrases of Kookaburra because of the separation to which I have referred. But Mr Hay's performance of the words of Kookaburra shows that a substantial part was taken. Moreover, although the question of quantity is secondary to that of quality, it is worthwhile noting that two of the four bars or phrases of Kookaburra have been reproduced in Down Under (or $50 \%$ of the song). ${ }^{41}$

Such a ruling could have dramatic repercussions for other forms of musical creativity. If the reproduction of a small segment of the Kookaburra song in a pub rock anthem is considered to be a substantial part, what hope is there for a mash-up to avoid a finding of copyright infringement?

EMI appealed, questioning whether the ruling of Jacobson J was consistent with High Court authority on substantiality. On appeal in 2011, the Full Court of the Federal Court of Australia upheld the original verdict. ${ }^{42}$ The presiding judges were Emmett, Jagot and Nicholas JJ.

In the most intriguing of the judgments, Emmett $\mathrm{J}$ reflected upon the usual formulae deployed in copyright law to interpret the definition of a musical work and a substantial part for the purposes of copyright infringement: 'In considering whether an alleged infringing work constitutes an infringement of a musical work, it is necessary to regard music as a language, with its own vocabulary and structure. ${ }^{43}$ Emmett J noted that 'music must be understood, by analogy, in the way in which traditional language is understood' ${ }^{44}$ His Honour commented: 'The word substantial is susceptible of some degree of ambiguity, and its meaning for the purposes of s 14 of the Copyright Act will be influenced by its context', ${ }^{45}$ and noted that '[t]he relevant context includes the development

\footnotetext{
${ }^{41}$ Ibid.

${ }^{42}$ Larrikin Appeal [2011] FCAFC 47 [11].

${ }^{43}$ Ibid [9].

${ }^{44}$ Ibid.

${ }^{45}$ Ibid [28].
} 
of copyright protection for specific kinds of works'. ${ }^{46}$ Emmett $\mathrm{J}$ noted that 'a melody, excerpt or phrase in a completed work is capable of manifesting originality'. ${ }^{47}$ Nonetheless, citing the work of Ronald Rosen, ${ }^{48}$ he observed that 'the copying of musical ideas and commonplace building blocks and motifs from a musical work, which are not themselves original, will not normally constitute infringement of that musical work'. ${ }^{49}$ On the facts of the case, Emmett J commented:

A four-part round is a musical idea, explicable in the abstract. That idea is not capable of copyright protection, just as other musical ideas and commonplace building blocks and motifs, such as bare musical genres, harmonic clichés and the like, are not capable of copyright protection. However, the specific melodies or phrases that constitute the expression of the idea of a four-part round will, in total, constitute an original musical work. Further, each melody or phrase may, by virtue of its importance in the overall schema of such an original musical work, constitute a substantial part of that work. I consider that the first two phrases of Kookaburra's melody, as published by Ms Sinclair in the form shown in Schedule 1, constitute a substantial part of Kookaburra. ${ }^{50}$

The judge noted, though, that there is no similarity between the respective natures and objects of the work: 'Kookaburra is a folk melody, children's song or nursery rhyme, while Down Under was characterised as a rock anthem, and is influenced by ska and/or reggae.' 51

Notwithstanding this ruling, Emmett J displayed reservations about the finding that the Down Under song had infringed the copyright in the Kookaburra song:

However, I have some disquiet about that conclusion in the circumstances of this case. The better view of the taking of the melody from Kookaburra is not that the melody was taken, animus furandi, in order to save effort on the part of the composer of Down Under, by appropriating the results of Ms Sinclair's efforts. Rather, the quotation or reproduction of the melody of Kookaburra appears by way of tribute to the iconicity of Kookaburra, and as one of a number of references made in Down Under to Australian icons. If, as I have concluded, the relevant versions of Down Under involve an infringement of copyright, many years after the death of Ms Sinclair, and enforceable at the

\footnotetext{
${ }^{46}$ Ibid.

${ }^{47}$ Ibid [11].

${ }^{48}$ Ronald S Rosen, Music and Copyright (Oxford University Press, 2008).

${ }^{49}$ Larrikin Appeal [2011] FCAFC 47.

${ }^{50}$ Ibid [97].

${ }^{51}$ Ibid [92].
} 
behest of an assignee, then some of the underlying concepts of modern copyright may require rethinking. ${ }^{52}$

His concern was that the test of substantiality is insensitive to a number of the circumstances of the case - particularly the use of the Kookaburra song as a quotation, reproduction, homage, or tribute.

Jagot J noted the grounds of appeal by EMI and Colin Hay:

The EMI parties and Mr Hay submitted that the trial judge made five key errors of principle described as: (i) adoption of an overly mechanistic analysis, (ii) failure properly to consider originality, (iii) failure to give due weight to the differences in aural perception, (iv) failure to inquire into animus furandi (that is, intending to take advantage of the skill and labour of the first author), and (v) erroneous reliance on the evidence of Mr Hay and Mr Ham. ${ }^{53}$

Jagot J supported the finding the trial judge:

As Larrikin submitted, the decisions on which the EMI parties and Mr Hay relied to support the materiality of these differences do not suggest that they represent the minimum criteria for a finding of reproduction of a substantial part of a copyright work. Accordingly, while it may be accepted that there is not a 'ready' aural perception of the bars of Kookaburra in the flute riff of Down Under, the bars are there and, as the trial judge found, can be heard once attention is directed to them. In terms of objective similarity, the bars are reproduced albeit in a different key and embedded in a different structure ... Characterising the borrowing as a tribute does not alter the fact of the borrowing. ${ }^{54}$

Jagot J held: 'In a case such as the present, where it is often said that questions of fact and degree are involved, an appellate court should not interfere with a trial judge's decision unless persuaded it is based on erroneous principle or plainly wrong'. 55

The Australian national airline Qantas fared somewhat better than Men at Work in the appeal. Jagot J (with whom Emmett J agreed) observed:

The trial judge was entitled on the evidence to reach the conclusion he did. Larrikin's alternative case (not pleaded but referred to in written submissions) based on the Qantas advertisements involving an adaptation of Kookaburra (ss 13(2), 31(1)(a)(iv) and 10(1) defining an adaptation of a

\footnotetext{
${ }^{52}$ Ibid [198]-[199].

${ }^{53}$ Ibid [168].

${ }^{54}$ Ibid [206]-[207].

${ }^{55}$ Ibid [227].
} 
musical work as an 'arrangement or transcription of the work'), cannot overcome the trial judge's conclusion that there is no reproduction of a substantial part of Kookaburra in the advertisements. ${ }^{56}$

This seems to be quite a fine distinction to be draw between the Men at Work version and the Qantas version of the song, Down Under - one is a copyright infringement; the other apparently not.

Applying the IceTV ruling, Nicholas $\mathrm{J}$ emphasised that the question whether a part of a work is a substantial part is to be determined by a 'consideration of its quality' and 'in assessing the quality of the part of the work in issue it may be necessary to consider whether the part was copied from another source or whether it is commonplace'. ${ }^{57}$ The judge held in the appeal:

As the primary judge found, Kookaburra is a relatively short piece consisting of only four bars. It was so described and analysed by both experts, Dr Ford and $\mathrm{Mr}$ Armiger ... While both experts appear to have accepted that Kookaburra is a relatively simple work, none suggested that any part of it lacked originality in the relevant sense. There was certainly no suggestion from either expert that any part of the composition had been borrowed by Miss Sinclair from any other source or that any of the musical phrases that make up the work was commonplace. ${ }^{58}$

The judge concluded that 'the evidence of the experts supported the view of the primary judge that this constitutes a substantial part of the work' ${ }^{59}$

The High Court of Australia considered a special leave application by EMI against the decision of the Full Court for the Federal Court of Australia. ${ }^{60}$

The barrister for Larrikin Records, Mr Lancaster, opposed the application for three reasons. The barrister said: 'The first is there are features of the case that make it unsuitable for any general examination of the question of infringement of copyright in musical works and referring there specifically to the concession made by the applicants as to the causal connection or actual use of "Kookaburra" in "Down Under"., 61 Secondly, the barrister argued that 'special leave should not be granted is the criticism that the judgments below were

\footnotetext{
${ }^{56}$ Ibid [236].

${ }^{57}$ Ibid.

${ }^{58}$ Ibid [266].

${ }^{59}$ Ibid [267].

${ }^{60}$ Transcript of Proceedings, EMI Songs Australia Pty Ltd v Larrikin Music Publishing Pty Ltd [2011] HCATrans 284 (Gummow and Bell JJ).

${ }^{61}$ Ibid.
} 
unduly mechanistic is not compelling'. ${ }^{62}$ Thirdly, the barrister maintained that 'there is no real doubt about the result, namely, that "Down Under" did reproduce a substantial part of "Kookaburra", ${ }^{63}$ He further noted: 'Justice Emmett, in the Full Court, who found arguable error by the trial judge and then addressed the question himself, came to the same conclusion. ${ }^{64}$ Rejecting the special leave application, Gummow J maintained: 'We are not satisfied that any question of principle respecting copyright infringement in musical works would be presented upon an appeal in this case rather than questions to the application of settled principle to the particular facts.' ${ }^{65}$ His Honour observed: 'Special leave is refused with costs. ${ }^{66}$

It is surprising that the Federal Court, the Full Federal Court, and the High Court did not explore much of the substantial comparative jurisprudence on copyright law and digital sampling. In the United States there has been much debate about a conflict between the approaches of the Court of Appeals for the $6^{\text {th }}$ Circuit with the Bridgeport case ${ }^{67}$ and the Court of Appeals for the $9^{\text {th }}$ Circuit in the Beastie Boys case ${ }^{68}$ in respect of digital sampling and de minimis use. Perhaps the United States Supreme Court will eventually need to intervene to resolve this ongoing dispute. There has been significant litigation over digital sampling of Kraftwerk in the European Union. ${ }^{69}$

\section{The Musical Community}

In his statement on the case, Colin Hay emphasised that Down Under did not use a substantial part of the Kookaburra song — indeed, in his view, the reference to the Girl Guide camp song was unrecognisable:

\footnotetext{
${ }^{62}$ Ibid.

${ }^{63}$ Ibid.

${ }^{64}$ Ibid.

${ }^{65}$ Ibid.

${ }^{66}$ Ibid.

${ }^{67}$ Bridgeport Music Inc v Dimension Films Inc, 410 F 3d 792 (6 ${ }^{\text {th }}$ Cir, 2005). See Janice Mueller, 'All Mixed Up: Bridgeport Music Dimension Films and de Minimis Digital Sampling' (2006) 81 Indiana Law Journal 435; M Leah Somoano, 'Bridgeport Music Inc Dimension Films: Has Unlicensed Digital Sampling of Copyrighted Sound Recordings Come to an End?’ (2006) 21 Berkeley Technology Law Journal 289; Steven Kim, 'Taking De Minimis out of the Mix: The Sixth Circuit Threatens to Pull the Plug on Digital Sampling in Bridgeport Music Inc Dimension Films' (2006) 13 Villanova Sports and Entertainment Law Journal 103.

${ }^{68}$ Newton v Diamond, 204 F Supp 2d 1244 (CD Cal, 2002); Newton v Diamond, 388 F 3d 1189 ( $9^{\text {th }}$ Cir 2004); Newton $v$ Diamond, 125 S Ct 2905 (2005).

${ }^{69}$ See Neil Conley and Tom Braegelmann (trans), 'English Translation: Metall auf Metall (Kraftwerk, et al v Moses Pelham et al), Decision of the German Federal Supreme Court no I ZR 112/06, dated November 20, 2008' (2009) 56 Journal of the Copyright Society 1017.
} 
Kookaburra is written as a round in a major key, and the Men At Work version of Down Under is played with a reggae influenced 'feel' in a minor key. This difference alone creates a completely different listening experience. The two bars in question had become part of a four bar flute part, thereby unconsciously creating a new musical 'sentence' harmonically, and in so doing, completely changed the musical context of the line in question, and became part of the instrumentation of Men At Work's arrangement of Down Under. $^{70}$

Hay lamented: 'What was born out of creative musical expression, became both a technical and mathematical argument." ${ }^{71}$ His concern is that the test for substantiality under copyright law has become a mechanical exercise - much more concerned with form, rather than substance.

Terry Noonan from the Musicians Union commented that the case also has ramifications for the definition of a musical work: 'In a sense it broadens the definition of what constitutes a song and what constitutes a significant part of a song., ${ }^{72}$ He noted: 'We're talking about something which is actually not part of the tune or the lyrics of this song, it's actually a line which is in the arrangement of the recording. ${ }^{73}$ The director of the Australian Songwriters Association, Denny Burgess, thought the judgment would encourage others to sue: 'Every songwriter, to a larger or lesser degree, is influenced by pieces of music, riffs etc that they have heard before, and they are bound to come through in the songs. ${ }^{74}$ The executive director of the Arts Law Centre of Australia, Robyn Ayres, said it was a 'warning to creative people that they have to be really careful when they are incorporating other people's work into their own' ${ }^{75}$

In his book, How to Make Gravy, the Australian singer-songwriter Paul Kelly discusses the role of imitation and innovation in a section entitled 'The Motley Cape'. ${ }^{76}$ He commented on some of the battles over musical appropriation:

Ever since Homer's repeated use of 'rosy-fingered dawn', 'wine dark sea' and other formulas in The Odyssey, songwriters have been drawing on the communal pool of phrases and images available to anyone with ears. In blues,

\footnotetext{
${ }^{70}$ Paul Cashmere, 'Colin Hay Calls Kookaburra Ruling Opportunistic Greed', Undercover (online), 7 February $2010<$ http://www.undercover.fm/news/10167-colin-hay-calls-kookaburraruling-opportunistic-greed $>$.

${ }^{71}$ Ibid.

${ }^{72}$ Ibid.

${ }^{73}$ Ibid.

${ }^{74}$ Ibid.

${ }^{75}$ Kim Arlington, 'Infringement Down Under’ The Sydney Morning Herald, 5 February 2010

$<$ http://www.smh.com.au/news/entertainment/news/2010/02/04/1265151932344.html>

${ }^{76}$ Kelly, above n 21, 66.
} 
folk, country and soul music - the building blocks of pop — words, lines, and whole verses have been swimming around forever from song to song. Melodies, too. Nearly all of Woody Guthrie’s tunes are borrowed.

I remember when sampling first became popular with the rise of hip-hop. A lot of musicians I knew, who prided themselves on being able to play their instruments properly, were dismissive. 'That's not music,' they sniffed. 'Anyone could do that.' But sampling made perfect sense to me; I'd been doing it since I first started making songs. ${ }^{77}$

Paul Kelly lamented: 'Some people continue to be surprised by this - those who have notions of the artist as some kind of self-dredger, dragging precious originality up from the depths of their soul., ${ }^{78} \mathrm{He}$ observed that 'self-expression is overrated, though' and 'a good line is worth using again and again'. ${ }^{79}$ Kelly noted that his work Change Your Mind is his 'patchwork quilt' and his 'motley cape': 'The stitching is visible but it works well — a good item to have in the kit as I go about my night-work'. ${ }^{80}$

The 2012 July edition of The Big Issue had a fascinating interview by Doug Wallen with Wouter de Backer - better known as Gotye - about his hit song, Somebody that I used to Know. ${ }^{81}$ Gotye observed that he has long engaged in digital sampling of musical works, while creating his own work. He noted that Somebody that I used to Know features a significant guitar sample from the 1967 instrumental track Seville by a jazz guitarist Luiz Bonfa from Brazil. The work has been legally cleared by Gotye. Nonetheless, Gotye complains that he still has had several music publishing companies trying to 'make a land grab for as much of my hit song as they can get' because of the role of the sample in the song. ${ }^{82}$ Gotye discusses how he seeks to make transformative uses of the material that he samples:

So that does play on your mind. But there's a line for me. I try to find the very incidental, secondary, almost forgotten sounds on obscure records: it might be the reverb trail on the guitar, or a chord that isn't the main hook. Especially if I work hard trying to re-pitch it, chop it up [and] put in a new context [so] it's hardly recognizable in my tune, I feel like my usage is a bit like when you buy a Les Paul guitar and put it through an Ibanez effects pedal ...

\footnotetext{
${ }^{77}$ Ibid 66-7.

${ }^{78}$ Ibid 66.

${ }^{79}$ Ibid.

${ }^{80}$ Ibid 67.

${ }^{81}$ Doug Wallen, ‘Somebody We’ve Got to Know', The Big Issue (Melbourne), 16 July 2012, 20.

${ }^{82}$ Ibid.
} 
I will sit down at a piano or listen to a bunch of records and grab little bits of them and try to put them together into some kind of hook or starting point for a song, and still be greeted with the same challenge. Which is: am I doing something that feels exciting and interesting to me? Vital, dare I say? Or at least stirring? Does it have a clear idea and direction? What am I trying to communicate with this? ${ }^{83}$

Gotye's co-producer, Francois Tetaz, observed that Gotye is 'at his most interesting when he's not able to do something and he tries to solve it with whatever skills he has' ${ }^{84}$ Interestingly enough, when Gotye initially sought to create Making Mirrors he planned on not using samples. Nonetheless, he observed: 'When I opened myself up again to sample records and use that as a process, it led to some of the simplest, most directive and effective songs on the album., ${ }^{85}$

Gotye has released an album of 10 official remixes of the song Somebody that I used to Know. He is conscious that the song has also inspired by a wide range of covers and remixes and parodies and karaoke pieces, on everything from YouTube to Glee. For instance, there is a Vancouver Canucks play-off song, based on Somebody that I used to Know - capturing the metaphysical anguish of losing the Stanley Cup play-offs in Game $7 .^{86}$ Gotye is ambivalent about requests to sample his hit song:

I use sampling as an inherent part of my songwriting process, so who am I to say no? But in the end I did say no. Because the song has become a hit at different stages [around the world], it [felt] like they're asking me for my permission to steal my thunder. To go, 'I'm gonna make your song a hit by putting a rap over the top of it,' before the song actually has a chance to come out on its own terms. ${ }^{87}$

At the same time, Gotye has been averse to pursuing litigation over unauthorised uses of his copyrighted work: 'I don't want to feel like a hypocrite about letting people use my material, which is why I don't ask anyone to go online and shut down parodies or covers or remixes.' ${ }^{88}$ Indeed, the creative artist has sought to celebrate the viral sampling and remixing of his hit song. Instead of suing for unauthorised uses of his copyright work, Gotye has released a compilation of cover versions of Somebody I used to Know, called Somebodies

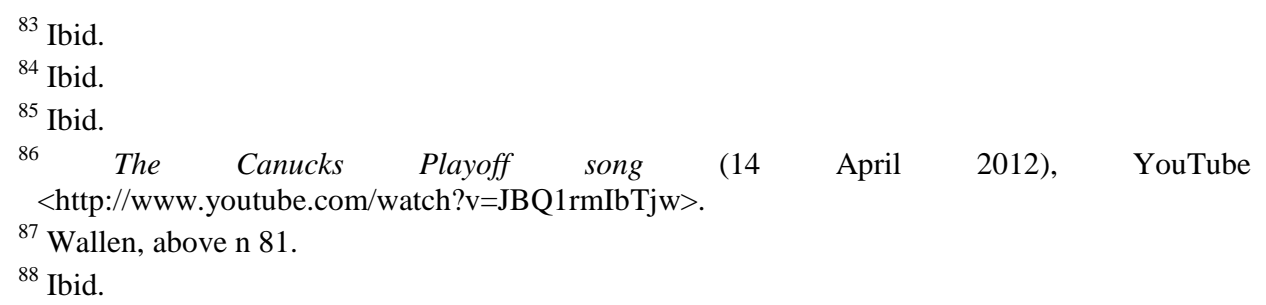


- A YouTube Orchestra ${ }^{89}$ The work has been a runaway success, being viewed millions of times. Indeed, Somebodies - A YouTube Orchestra has provoked a wider discussion about copyright law, digital sampling, and remix culture in the context of the ALRC inquiry into copyright law and the digital economy. ${ }^{90}$

Musical mash-ups ${ }^{91}$ raise even more complicated questions about substantiality. In his documentary, RiP!: A Remix Manifesto, Brett Gaylor focuses upon the work of Gregg Gillis, known by the alias Girl Talk. ${ }^{92}$ A DJ and mash-up artist, Girl Talk has released several albums, including Secret Diary (2002), Unstoppable (2004), Night Ripper (2006), Feed the Animals (2008), and All Day (2010). His work features remixes of dozens of samples of musical works and sound recordings. In his book, Remix, Lawrence Lessig hails Girl Talk as an exemplar of 'Remix culture'. ${ }^{93}$ In an interview with The Age, Gregg Gillis discusses the political implications of RiP!: A Remix Manifesto. ${ }^{94}$ He observes of the future of the cultural form of mash-ups:

Mash-ups are one small area of sample-based music but they are going to become a bigger part of the musical landscape as people become more and more connected to computers. In the last 20 years, sampling has been responsible for some of the most important albums from bands like Daft Punk and the Avalanches. There are a million remixes done for every pop song released these days and YouTube is full of remixes of previously existing media. In five years everyone will have computers in their pockets and everyone will know how to draw, edit and make collages and it's going to be as common to make music on computers as guitars. ${ }^{95}$

His suggestion is the cultural form of the 'mash-up' will become commonplace, part of the mainstream of cultural creation and production, rather than an unusual novelty.

89 Gotye, Somebodies: A YouTube Orchestra (12 August 2012), YouTube $<$ http://www.youtube.com/watch?v=opg4VGvyi3M>.

${ }^{90}$ Asher Moses, 'Copyright Stuck in a Horse and Buggy Era', The Age (online), 21 August 2012 $<$ http://www.theage.com.au/technology/technology-news/copyright-stuck-in-horse-and-buggyera-20120821-24jrl.html>.

91 Franzen and McLeod, above n 16; Kembrew McLeod, 'Confessions of an Intellectual (Property) Academic: Danger Mouse, Mickey Mouse, Sonny Bono, and My Long and Winding Path as a Copyright Activist' (2005) 28(1) Popular Music and Society 79.

${ }^{92}$ Gaylor, above $n 18$.

${ }^{93}$ Lawrence Lessig, Remix: Making Art and Commerce Thrive in the Hybrid Economy (Penguin, 2008) 12.

94 Patrick Donovan, 'Variety is the Splice of Life', The Age (online), 8 January 2010 $<$ http://www.theage.com.au/articles/2010/01/07/1262453637393.html>.

${ }^{95}$ Ibid. 
There has been wider discussion about the ramifications of the Kookaburra case for copyright law and remix culture, more generally. ${ }^{96}$

\section{COPYRIGHT EXCEPTIONS}

The Kookaburra case has also raised larger questions about the nature and scope of copyright exceptions in Australia.

In the Full Federal Court of Appeal, Emmett $\mathrm{J}$ alluded in his judgment to the question of copyright exceptions, referring to the question of the defence of fair use: 'Nevertheless, one may wonder whether the framers of the Statute of Anne and its descendants would have regarded the taking of the melody of Kookaburra in the Impugned Recordings as infringement, rather than as a fair use that did not in any way detract from the benefit given to Ms Sinclair for her intellectual effort in producing Kookaburra., ${ }^{97}$

In the High Court, there was an interesting exchange between Mr Gleeson and Gummow $\mathrm{J}$ on the question of the transformative nature of the material:

Mr Gleeson: We agree. His Honour then says at paragraph 101, the fact that that is an infringement troubles him. Our answer to that question is legally it should not have troubled his Honour for this reason, that the act of creation of the second work involved a sufficient degree of transformation of the part taken from the first work so as to place it within the territory of legitimate appropriation outside the statutory monopoly. Your Honours, that is where the question raises -

Gummow J: ... attributed to the so-called 'iconicity', whatever that is, of Kookaburra, you might ask yourself, 'Gee, is this in copyright still?'

Mr Gleeson: Where the issue then arises, your Honour, which goes well beyond music to -

Gummow J: Anyhow, these are all questions of policy of a copyright statute. ${ }^{98}$

${ }^{96}$ ABC Radio National, 'Are We All Copyright Criminals?', Late Night Live, 24 October 2012 (Phillip Adams) <http://www.abc.net.au/radionational/programs/latenightlive/are-we-allcopyright-criminals3f/4331714>; Panel discussion with Matthew Rimmer; Geordie Williamson, Chief Literary Critic of The Australian newspaper and author of The Burning Library; and Lee Sternthall, co-director and co-writer of The Words and Tron Legacy.

${ }^{97}$ Larrikin Appeal [2011] FCAFC 47 [101].

98 Transcript of Proceedings, EMI Songs Australia Pty Ltd v Larrikin Music Publishing Pty Ltd [2011] HCATrans 284 (Gummow and Bell JJ). 
The Court would appear to be indicating that such matters should be left to the parliament to resolve.

Indeed, the Kookaburra dispute has figured significantly in respect of the ALRC's inquiry into Copyright and the Digital Economy. ${ }^{99}$ President Rosalind Croucher has stated: 'It is a complex and important area of law and we are looking forward to some robust debate and discussion during the course of this very important Inquiry. ${ }^{100}$ There have been a number of policy options presented to address the question of copyright law and digital sampling. Some maintain that existing copyright exceptions are sufficient. Others have called for the introduction of new purpose specific defences - such as a defence for quotation, a defence of transformative use, or a defence for non-commercial remixes. There has been a powerful push for a defence of fair use in Australia, particularly to address creative work. There has also been a discussion of the use or the extension of statutory licensing to deal with digital sampling.

\section{A A Defence for Transformative Uses in Australia}

The current Copyright Act 1968 (Cth) has a defence of fair dealing, which provides protection against claims of copyright infringement. The defence is limited to particular purposes — such as research and study, criticism and review, reporting the news, use for judicial proceedings, and parody and satire (introduced in 2006). ${ }^{101}$

The courts have also expressed great frustration at the lack of legislative action in respect of the defence of fair dealing. Most notably, in the long-running 'Panel case', the Federal Court of Australia struggled to provide clear guidance as to the operation of the defence of fair dealing. ${ }^{102}$ The determination of fair dealing seemed to depend upon very much upon subjective judicial impressions of the facts of individual cases. There appeared to be little in the way of overarching principles guiding such decisions beyond the phenomenology of the judiciary. In Network Ten Pty Ltd v TCN Channel Nine Pty Ltd, the High Court emphasised that it was a question for parliament to reform the current defence of fair dealing. ${ }^{103}$ Kirby J observed: 'To the extent that it is suggested that the

99 ALRC, Copyright and the Digital Economy, Issues Paper No 42 (2012) $<$ http://www.alrc.gov.au/publications/copyright-ip42>.

${ }^{100}$ ALRC, 'Terms of Reference Received for the ALRC Copyright Inquiry' (Press Release, 29 June 2012) <http://www.alrc.gov.au/news-media/media-release/terms-reference-received-alrccopyright-inquiry $>$.

${ }^{101}$ Copyright Amendment Act 2006 (Cth).

102 TCN Channel Nine v Network Ten (2001) 108 FCR 235; TCN Channel Nine Pty Ltd v Network Ten (2002) 118 FCR 417.

${ }^{103}$ Network Ten Pty Ltd v TCN Channel Nine Pty Ltd (2004) 59 IPR 1. 
fair dealing defence under the Act is unduly narrow, that submission should be addressed to the Parliament." ${ }^{104}$ His Honour further observed: 'The correction of any remaining defects is a matter for the Parliament. It is not for this Court. ${ }^{105}$

In 2006, the federal government did add a new defence of fair dealing in respect of parody and satire, and a number of other particular copyright exceptions. ${ }^{106}$ The Attorney-General, Philip Ruddock, emphasised the need for such a defence:

Australians have always had an irreverent streak. Our cartoonists ensure sacred cows don't stay sacred for very long and comedians are merciless on those in public life. An integral part of their armoury is parody and satire or, if you prefer, 'taking the micky' out of someone. ${ }^{107}$

Sally McCausland, a senior lawyer with SBS, has commented on the scope of the exception: 'The Australian Government has provided greater freedom for Australian comics, cartoonists, writers, artists, performers and political commentators to use copyright material in the practice of Australia's "fine tradition of satire"., 108 Maree Sainsbury has also written about the nature and the scope of the new defence of fair dealing in respect of parody and satire. ${ }^{109}$ The defence of fair dealing in Australia would benefit from an expansive reading - much like the Supreme Court of Canada has engaged in a broad reading of the defence of fair dealing in Canada. ${ }^{110}$

\footnotetext{
${ }^{104}$ Ibid.

${ }^{105}$ Ibid.

${ }^{106}$ Copyright Act 1968 (Cth) ss 41A, 103AA (Fair Dealing for Parody or Satire); s 111 (Timeshifting television broadcasts); s 109A (Space-shifting sound recordings); s 111AA (Formatshifting cinematographic films); s 43C (Format-shifting books, newspapers and periodical publications); s 47J (Format-shifting photographs); ss 51A, 110BA (Cultural preservation); and s 200AB (Flexible dealing provision).

107 Philip Ruddock, 'Protecting Your Right to Mock', The Daily Telegraph (Sydney), 30 November 2006.

${ }^{108}$ Sally McCausland, 'Protecting “A Fine Tradition of Satire”: The New Fair Dealing Exception for Parody or Satire in The Australian Copyright Act' (2007) 29(7) European Intellectual Property Review 287.

109 Maree Sainsbury, 'Parody, Satire and Copyright Infringement: The Latest Addition to Australian Fair Dealing Law’ (2007) 12(3) Media and Arts Law Review 292; Maree Sainsbury, 'Parody, Satire, Honour and Reputation: The Interrelationship of the Defence of Fair Dealing for the Purposes of Parody and Satire and the Author's Moral Rights' (2007) 18 Australian Intellectual Property Journal 149.

${ }^{110}$ Building upon its decision in CCH Canadian Ltd v Law Society of Upper Canada [2004] 1 SCR 339, the Supreme Court of Canada handed down a pentalogy of copyright cases in 2012, including Entertainment Software Association v Society of Composers, Authors and Music Publishers of Canada 2012 SCC 34; Rogers Communications Inc v Society of Composers, Authors and Music Publishers of Canada 2012 SCC 35; Society of Composers, Authors and Music Publishers of Canada v Bell Canada 2012 SCC 36; Alberta (Education) v Canadian
} 
The ALRC, led by the redoubtable Professor Jill McKeough, has been asked to inquire into copyright exceptions. The Terms of Reference ask the Commission to consider whether copyright exceptions should allow 'transformative, innovative and collaborative' use of copyright materials to create and deliver new products and services. ${ }^{111}$ In the Issues Paper, the ALRC frames the issue of 'transformative use' in these terms:

In this Issues Paper, the term 'transformative' is used to refer generally to works that transform pre-existing works to create something new and that is not merely a substitute for the pre-existing work. Works that are considered transformative may include those described as 'sampling', 'remixes' and 'mashups'. Such uses may be commercial — as in the case of music released commercially that uses samples of existing tracks - or non-commercial, such as where copyright material is used in online user-generated content. A number of law reform and other bodies in Australia and overseas have recommended changes to copyright laws that would provide broader exceptions permitting transformative use of copyright materials. ${ }^{112}$

The Issues Paper notes that authors often 'draw upon pre-existing works and transform expression from them in creating new works that criticize, comment upon, or offer new insights about those works and the social significance of others' expressions' - parodies are a classic example of this kind of transformative use' ${ }^{113}$ The Issues Paper notes that two forms of transformative uses are music sampling - 'the act of taking a part, or sample, of one sound recording and reusing it in a different composition' and mashups - 'a song created by blending two or more songs, usually by overlaying the vocal track of one song onto the music track of another'. ${ }^{114}$

Professor Elizabeth Adeney suggested at the Deakin Law School conference that a copyright defence could focus upon quotations, in line with the Berne Convention. ${ }^{15}$ She referred to art 10(1) of the Berne Convention, which provides: 'It shall be permissible to make quotations from a work which has already been lawfully made available to the public, provided that their making is

Copyright Licensing Agency (Access Copyright) 2012 SCC 37; Re Sound v Motion Picture Theatre Associations of Canada 2012 SCC 38. For a commentary, see Michael Geist, 'Supreme Court of Canada Stands Up for Fair Dealing in Stunning Sweep of Cases' on Michael Geist's Blog (12 July 2012) <http://www.michaelgeist.ca/content/view/6588/125/>.

${ }^{111}$ ALRC, Terms of Reference (29 June 2012) <http://www.alrc.gov.au/inquiries/copyright/termsreference>

${ }^{112}$ ARLC, above n 99, 36.

${ }^{113}$ Ibid 37.

${ }^{114}$ Ibid 37.

115 Elizabeth Adeney, 'The Sampling and Remix Dilemma: What is the Role of Moral Rights in the Encouragement and Regulation of Derivative Creativity?' (2012) 17 Deakin Law Review 335. 
compatible with fair practice, and their extent does not exceed that justified by the purpose, including quotations from newspaper articles and periodicals in the form of press summaries.' 116 Professor Sam Ricketson and Professor Jane Ginsburg commented: 'Although Article 10(1) does not define "quotation”, this usually means the taking of some part of a greater whole - a group of words from a text or a speech, a musical passage or visual image that from a piece of a work of art - where the taking is done by someone other than the originator of the work'. ${ }^{117}$ The ALRC noted: 'There have been suggestions that art 10(1) of the Berne Convention — which imposes a mandatory obligation to provide a specific exception for quotation - could be usefully employed in Australia as the basis for an exception for non-commercial transformative use; an exception permitting the quotation of copyright works in commercial works; or an exception for fair dealing for the purpose of quotation.' ${ }^{118}$ The ALRC 'is interested in comments about whether there should be a fair dealing exception for the purpose of quotation or any other specific fair dealing exceptions'. ${ }^{119}$ A defence of fair dealing for quotation would seem to be limited in its operation. The Down Under song may use a quotation of the Kookaburra song, but it also transforms the work, and changes its meaning and context. My reservation would be that the term 'quotation' is somewhat anachronistic, and does not necessarily capture a full range of transformative uses - such as forms of digital sampling, remixes, and mash-ups.

The ALRC poses the question: 'Should a transformative use exception apply only to: (a) non-commercial use; or (b) use that does not conflict with a normal exploitation of the copyright material and does not unreasonably prejudice the legitimate interests of the owner of the copyright? ${ }^{, 120}$ The Australian Copyright Council (with close connections with Australia's copyright collecting societies; copyright industries and professional creative artists) has established a Cabinet of Expert Advisors on copyright law reform. This group has proposed a nominal, minimal exception for non-commercial, transformative use. ${ }^{121}$ The group observed 'that an exception permitting private, non-commercial, transformative uses would preserve the balance in copyright law between interests of creators and users, and preserve public respect for the relevance and

\footnotetext{
${ }^{116}$ Berne Convention for the Protection of Literary and Artistic Works (Paris Act), opened for signature 24 July 1971, [1978] ATS 5 (entered into force on 15 December 1972) art 10(1).

117 Sam Ricketson and Jane Ginsburg, International Copyright and Neighbouring Rights: The Berne Convention and Beyond (Oxford University Press, 2006) 788.

${ }^{118}$ ALRC, above $\mathrm{n} 99$.

${ }^{119}$ Ibid 69.

${ }^{120}$ Ibid 40.

${ }^{121}$ The Australian Copyright Council Expert Group, Directions in Copyright Reform in Australia (2011) Australian Copyright Council <http://www.copyright.org.au/pdf/Copyright\%20Council\%20Expert\%20Group\%20\%20Paper\%202011.pdf>.
} 
integrity of copyright law'. ${ }^{122}$ This is, in my opinion, a 'shadow solution'. The problem with this proposal is that it conflates two very different defences: (1) a defence for private, non-commercial use; and (2) a defence for transformative use. With respect, I think that such an exception is unduly conservative and would be concerned that such a proposal would stifle innovation and creativity.

The unnecessary, double limitation that a transformative use be both private and non-commercial goes against the grain of existing Australian defences. The defence of fair dealing for parody or satire has no such qualifications or limitations or constrictions. The defence of reasonableness under moral rights is not solely available for private and non-commercial uses. Moreover, such a defence on private, non-commercial transformative use is in direct contradiction with the United States jurisprudence on fair use, which allows for public and commercial transformative uses (look at the Naked Gun case, for instance). ${ }^{123}$ It is unclear to me why creative artists could only engage in transformative use, in the privacy of their own home, with no professional aspirations. The very narrow sliver of protection offered by such an exception would be outweighed by the broad exposure to liability for creative artists for public and/or commercial transformative uses. It should also be noted that in the United States even some non-transformative uses are protected under the defence of fair use in the United States - because transformative use is a factor but not necessarily the sole, definitive test.

\section{B A Defence of Fair Use for Australia}

In its Issues Paper, the ALRC specifically broaches the question of whether there should be a defence of fair use in Australia:

Australian legislation has long provided for exceptions to copyright based on what is understood now to be a closed list of permitted purposes for 'fair dealing'. By contrast, since 1976, the United States legislation has provided for a broad exception to copyright based on an open list of permitted purposes for 'fair use'. The legislative provisions for 'fair dealing' that are found in countries such as the UK and Australia, and for the US-style 'fair use' share the same common law source: early English cases that were often concerned with an exception for abridgments. ${ }^{124}$

The ALRC poses the question: 'Should the Copyright Act 1968 (Cth) be amended to include a broad, flexible exception?" ${ }^{125}$ Furthermore, the

\footnotetext{
${ }^{122}$ Ibid.

${ }^{123}$ Leibovitz v Paramount Pictures Corporation, 948 F Supp 1214 (SD NY, 1996).

${ }^{124}$ ALRC, above n 99, 71

${ }^{125}$ Ibid 79.
} 
Commission queries: 'Should such a new exception replace all or some existing exceptions or should it be in addition to existing exceptions?' ${ }^{126}$

In a piece entitled, 'A Fair Use Project for Australia', I argued that there is a need to reform Australian copyright law in order to protect creative freedom. ${ }^{127}$ There is a need for the Australian government to introduce a defence of fair use, like its United States counterparts, particularly to allow for creative, transformative uses. Such a defence would have provided important protection for Colin Hay, Greg Ham, and Men at Work in respect of the musical work Down Under - especially given that it was strongly transformative of the Kookaburra work. Arguably, if Australia had a defence of fair use, Colin Hay, Greg Ham, and Men at Work would have been protected against the threat of copyright litigation by Larrikin Records. Although Down Under is a commercial work, it is undoubtedly transformative of the original Kookaburra song. Down Under is certainly no substitute for the Kookaburra; indeed, the two works operate in entirely different musical fields. The Down Under work did not affect the market for the Kookaburra song. Arguably, Australia should adopt an open-ended, multi-factorial defence of fair use. Indeed, it has had a remarkably similar defence of reasonableness for a decade under the moral rights regime. In the field of patent law, the Australian government has also introduced an open-ended, multi-factorial defence for experimental use, with the Intellectual Property Laws Amendment (Raising the Bar) Act 2012 (Cth).

It should be acknowledged that the defence of fair use has been interpreted in various ways in the United States. Professor Michael Madison has observed that there is a 'pattern-oriented approach to fair use' in the United States courts. ${ }^{128}$ Professor Pamela Samuelson has observed that the defence of fair use has applied in a wide variety of cultural contexts and technological fields:

Fair use has been invoked as a defense to claims of copyright infringement in a wide array of cases over the past thirty years, as when someone has drawn expression from an earlier work in order to parody it, quoted from an earlier work in preparing a new work on the same subject, published a photograph as part of a news story, made a time-shift copy of television programming, photocopied a document for submission as evidence in a litigation, reverse engineered a computer program to get access to interface information, cached

\footnotetext{
${ }^{126}$ Ibid 79.

${ }^{127}$ Matthew Rimmer, 'A Fair Use Project for Australia: Copyright Law and Creative Freedom' (2010) 28(3) Copyright Reporter 165.

${ }^{128}$ Michael Madison, 'A Pattern-Oriented Approach to Fair Use' (2004) 45 William and Mary Law Review 1525.
} 
websites to facilitate faster access to them, or provided links to images available on the Internet, just to name a few. ${ }^{129}$

In his encyclopaedic coverage of copyright exceptions, William Patry highlights variations in approaches and outcomes in fair use determinations in the United States. ${ }^{130}$ There has been much debate about whether the defence of fair use would apply to cases of musical mash-ups. ${ }^{131}$

In the United States, there has been scholarly debate about the reformation and refinement of the defence of fair use. In Creative License, McLeod and DiCola have various recommendations about the defence of fair use and its operation in respect of musical works and digital sampling:

In terms of legislative intervention, Congress could reduce the uncertainty surrounding fair use. For instance, it could amend section 107 of the federal copyright code, which codifies the fair use doctrine to clarify whether a sample-based song that is not a parody can qualify as a transformative use at least in some cases. Such a signal might spur various stakeholders in the music industry to work out a set of guidelines about which uses count as fair. The federal courts could also implement a clearer way to address fair use in sampling cases, perhaps by including a workable definition of transformative uses for cases that don't involve parodies. ${ }^{132}$

Nonetheless, McLeod and DiCola recognise that '[r]ealistically, though, it is unlikely that Congress would be motivated to alter the copyright code for the benefit of such a small class of constituents - remixers - and there is no guarantee that legislators would get it right'. ${ }^{133}$ Moreover, they fear that 'it's quite possible that Congress could make things worse by retooling the federal copyright code, especially given the lobbying power and influence of the entertainment industries that have Congress's ear'. ${ }^{134}$ Such fears of government

\footnotetext{
${ }^{129}$ Pamela Samuelson, 'Unbundling Fair Uses’ (2009) 77 Fordham Law Review 2537, 2539. See also Pamela Samuelson, 'Book Review: Is Copyright Reform Possible?' (2013) 126 Harvard Law Review 740. Samuelson observed that social norms could be a powerful engine of law reform: 'A more positive reform through social norms has been the rising acceptance of usergenerated content such as remixes and mashups of copyrighted content, including clips from motion pictures, fan-fiction rewriting of stories, and the like.'

${ }^{130}$ William Patry, Patry on Fair Use (Thomson Reuters, 2012).

${ }^{131}$ For various perspectives on copyright, the defence of fair use, and mash-ups, see David Mongillo, 'The Girl Talk Dilemma: Can Copyright Law Accommodate New Forms of SampleBased Music?'(2009) 10 The University of Pittsburgh Journal of Technology Law and Policy 3; Victoria Elman and Alex Middleton, 'Girl Talk on Trial: Could Fair Use Prevail?'(2009) Cardozo Law Review De Novo 149; Shervin Rezaie, 'Play Your Part: Girl Talk’s Indefinite Role in the Digital Sampling Role’ (2010) 26 Touro Law Review 175.

${ }^{132}$ McLeod and DiCola, above n 16, 243.

${ }^{133}$ Ibid 243.

${ }^{134}$ Ibid.
} 
capture have no doubt been fuelled by developments such as congressmen sponsoring diabolical legislative regimes, such as the Stop Online Piracy Act 2011 (US) and the Protect Intellectual Property Act 2011 (US). ${ }^{135}$

In his book, Copyfraud and other Abuses of Intellectual Property Law, Jason Mazzone contends that the United States Congress should establish a new agency within the federal government to protect the defence of fair use, and that the Department of Justice should create a bureau to protect the public interest in the public domain and the intellectual commons. ${ }^{136}$ Such recommendations emphasise that there is a need for institutional support for copyright defences, exceptions and limitations, and the broader public interest under copyright law. In this context, there is a need to contemplate what institutional support could be provided for copyright exceptions in Australia.

In Reclaiming Fair Use: How to Put Balance Back in Copyright, Pat Aufderheide and Peter Jaszi make a strong case for the virtues of a broad and flexible reading of the defence of fair use in the United States. ${ }^{137}$ The pair lament that 'copyright has become long and strong', 138 and that 'current owners have gained power over future creators and the culture, and fair use has become more important in freeing future creators from the death grip of the past'. ${ }^{139}$ They comment that the defence of fair use should be reclaimed, so that the defence plays an important role in promoting creative expression and freedom of speech:

Reclaiming fair use plays a particular and powerful role in the broader range of activities that evidence the poor fit between today's copyright policy and today's creative practices. In a world where the public domain has shrunk drastically, it creates a highly valuable, contextually defined, 'floating' public domain. The assertion of fair use is part of a larger project of reclaiming the full meaning of copyright policy - not merely protection for owners, but the nurturing of creativity, learning, expression. Asserting and defending fair-use rights are a crucial part of constructing saner copyright policy. ${ }^{140}$

\footnotetext{
${ }^{135}$ For a commentary, see Mark Lemley, David Levine and David Post, 'Don't Break the Internet' (2011) 64 Stanford Law Review Online 34.

136 Jason Mazzone, Copyfraud and Other Abuses of Intellectual Property Law (Stanford University Press, 2011).

137 Aufderheide and Jaszi, above n 17. For a review, see Matthew Rimmer, 'Not all Rights are Reserved; A Book Review of Reclaiming Fair Use: How to Put Balance Back in Copyright by Patricia Aufderheide and Peter Jaszi' (2012) Times Higher Education (online), 12 January 2012

$<$ http://www.timeshighereducation.co.uk/story.asp?sectioncode=26\&storycode=418632\&c=1>.

${ }^{138}$ Aufderheide and Jaszi, above n 17, 33.

${ }^{139}$ Ibid.

${ }^{140}$ Ibid 16.
} 
Aufderheide and Jaszi promote the use of community guidelines within creative communities. They observe: 'To the extent that communities of practice can articulate how they understand their fair-use rights, and describe them within the terms of their practice (rather than having people individually measure their practice against the highly abstract four factors), they can strengthen not only their own understanding, but the ability of lawyers and judges to make reasonable decisions'. ${ }^{141}$

As might be expected, established copyright industries and their associates, such as the Australian Copyright Council have been hostile to the introduction of a defence of fair use to Australian copyright law. In his book, How to Fix Copyright, William Patry has warned: 'The rhetorical device of turning fair use into a moral panic is made by those who oppose adapting copyright to the digital era.' ${ }^{142}$ He notes that 'fair use thus serves as a classic moral panic: an effort by vested interests to preserve the status quo through creating a false enemy whom, we are told, must be vanquished for the alleged good of society as a whole'. ${ }^{143}$ Patry maintains: 'Far from being an alien concept, fair use arises out of the fundamental purpose of copyright: encouraging the creation of new works, or providing new insights into old ones. ${ }^{\text {, }}{ }^{44}$

\section{A Reform of Statutory Licensing in Australia}

The dispute over the Kookaburra case has also raised the question of whether statutory licensing would be an effective means of addressing digital sampling, remixes, and mash-ups.

In its Issues Paper, the ALRC has requested submissions on the operation of statutory licenses in the digital environment. ${ }^{145}$ The Commission has asked: 'What opportunities does the digital economy present for improving the operation of statutory licensing systems and access to content? ${ }^{146}$ The Commission asks the questions: 'How can the Copyright Act 1968 (Cth) be amended to make the statutory licensing schemes operate more effectively in the digital environment - to better facilitate access to copyright material and to give rights holders fair remuneration?' and 'Should the Copyright Act

\footnotetext{
${ }^{141}$ Ibid 93.

${ }^{142}$ William Patry, How to Fix Copyright (Oxford, 2012) 211.

${ }^{143}$ Ibid 212.

${ }^{144}$ Ibid.

${ }^{145}$ ALRC, above n 99, 61.

${ }^{146}$ Ibid 62.
} 
1968 (Cth) be amended to provide for any new statutory licensing schemes, and if so, how? ${ }^{147}$

In this context, there has been a lively debate about the use of statutory licensing or alternative compensation schemes in respect of digital sampling, remixes, and mash-ups.

In the United States, similar sentiments were expressed at the passing of one of the members of the Beastie Boys, Adam Yauch. ${ }^{148}$ Julie Samuels of the Electronic Frontier Foundation (EFF) observed:

Today's sad news of the passing of Adam Yauch, the Beastie Boy's MCA, caused us to take a moment to reflect on the impact that the Beastie Boys, and their seminal record Paul's Boutique, had on remix culture.

Released in 1989, Paul's Boutique reportedly contains somewhere between 100 and 300 samples. In fact, one of the engineers who worked on the record estimated that '95\% of the sounds' on Paul's Boutique came from samples. Paul's Boutique went on to garner both critical acclaim and commercial success, and it's no wonder. Along with records by De La Soul and Public Enemy, it broke new ground in remixing all kinds of samples and laid the groundwork for many of today's popular artists, such as Girl Talk. ${ }^{149}$

Samuels commented: 'We think it's pretty clear that the samples the Beastie Boys used in Paul's Boutique and that Girl Talk now uses in his records are classic examples of fair use.' ${ }^{150}$ She lamented: 'Unfortunately, many artists these days are nonetheless under pressure to pay licensing fees for similar uses. ${ }^{151}$

Indeed, the Beastie Boys have been the subject of litigation in the past. In the case of Newton $v$ Diamond, the jazz flutist and composer, James W Newton, claimed that the Beastie Boys had sampled a six-second, three-note performance of his composition Choir. In 1992, the Beastie Boys obtained a licence from ECM Records to use portions of the sound recording of Choir in various renditions of their song Pass the Mic in exchange for a one-time fee of $\$ 1000$.

\footnotetext{
${ }^{147}$ Ibid.

148 Editorial, 'Beastie Boys Co-Founder Adam Yauch Dead at 47: Influential Rapper was Diagnosed with Cancer in 2009', Rolling Stone (online), 4 May 2012 $<$ http://www.rollingstone.com/music/news/beastie-boys-co-founder-adam-yauch-dead-at-4820120504>.

149 Julie Samuels, 'RIP MCA: A Tribute to Paul's Boutique and Electronic Sampling', The Electronic Frontier Foundation, 4 May $2012<$ https://www.eff.org/deeplinks/2012/05/rip-mcatribute-pauls-boutique-and-music-sampling $>$.

${ }^{150}$ Ibid.

${ }^{151}$ Ibid.
} 
Beastie Boys did not obtain a licence from Newton to use the underlying composition. At first instance, the District Court granted summary judgment that there was no copyright infringement in favour of the defendants. ${ }^{152}$ For the majority, Schroeder CJ of the $9^{\text {th }}$ Circuit Court of Appeals affirmed that the Beastie Boys' use was a de minimis use and therefore not actionable. ${ }^{153}$ This case is an important precedent in the field of copyright law and digital sampling.

Nonetheless, the Beastie Boys and the late Adam Yauch were sued once again for copyright infringement in 2012. The newspaper report highlighted the nature of the dispute:

The suit alleges that Trouble Funk's tracks Drop the Bomb and Say What, both issued in 1982, were sampled repeatedly by Beastie Boys in the late 80s. The lawsuit was filed in New York federal court on Friday. Yauch died on Saturday morning. According to Tuf America's complaint, the Beasties' song Shadrach allegedly samples Say What, while Drop the Bomb is apparently used on two tracks from the rappers' debut album, as well as on Car Thief, from 1989's Paul's Boutique. Although the statute of limitation for copyright infringement has passed, Tuf America say the Beastie Boys never declared the samples had been used, and accuse the group of 'purposely concealing the integration' of Trouble Funk's original music. 'Only after conducting a careful audio analysis of Shadrach,' they wrote, '[were we] able to determine that Shadrach incorporates the Say What sample.'

In TufAmerica Inc v Diamond, the plaintiff complains: 'This case is about the illegal "sampling," or use without permission of a portion of an existing recording as part of another recording, committed by one or more of the defendants in connection with at least four recordings attributed to the group known as the "Beastie Boys", ${ }^{155}$ TufAmerica sought to recover damages for the alleged copyright infringement and other torts by the Beastie Boys, and to enjoin the further distribution of the works.

Julie Samuels of the EFF laments: 'Despite the fact that most cases rightfully find that sampling is not copyright infringement, the mere threat of a lawsuit (and the spectre of statutory damages) is enough to intimidate musicians and

\footnotetext{
${ }^{152}$ Newton v Diamond, 204 F Supp 2d 1244 (CD Cal, 2002).

${ }^{153}$ Newton v Diamond, 388 F 3d 1189, 1197 ( $9^{\text {th }}$ Cir, 2004).

${ }^{154}$ Sean Michaels, 'Beastie Boys Sued over Alleged Copyright Infringement', The Guardian, 9 May 2012 (online), <http://www.guardian.co.uk/music/2012/may/09/beastie-boys-allegedcopyright-infringement $>$.

${ }^{155}$ TufAmerica v Diamond, 12 Civ 3529 (SD NY, 2012).
} 
labels alike. ${ }^{, 156}$ She advocated the creation of an effective licensing scheme for digital sampling:

The time to come up with a new, effective licensing scheme is long overdue. Young artists should be encouraged to remix and create in all the exciting new ways that technology allows, not sidelined by expensive licensing battles. Solving this problem would go a long way in that direction and be a fitting tribute to MCA, the Beastie Boys, and the fantastic remix culture they helped foster. ${ }^{157}$

There are a range of models dealing with voluntary licensing, compulsory licensing, and compensation schemes. William Fisher has proposed an alternative compensation scheme in his book Promises to Keep. ${ }^{158}$

In Creative License, McLeod and DiCola discuss the challenges faced by the Beastie Boys in clearing copyright samples. ${ }^{159}$ Summarising this research, the pair observe that key albums such as the Beastie Boys' Paul's Boutique would be impossible to make today:

In looking two sample-heavy albums released in 1989 and 1990 — the Beastie Boys' Paul's Boutique and Public Enemy's Fear of a Black Planet - we estimate that they probably would not be released today without taking a significant loss on each copy sold. (And this is assuming that all the samples contained on those albums could be cleared successfully, which is highly doubtful.) These fiscal and legal realities deter the creation of collaged compositions containing multiple samples, thereby stunting the development of an art form in its relatively early stages. ${ }^{160}$

McLeod and DiCola recognise that 'no single reform can fix the deficiencies in sample licensing'. ${ }^{161}$ The pair fear that 'the royalty stacking problem for sample-heavy musical collages, for example, may require more fundamental reform than the inefficiency that sometimes hinders clearances for major-label artists'. ${ }^{162}$ They comment: 'Because the music industry of both copyright law and private industry, the best approach to the sample clearance system's shortcomings is a set of legal and business reforms that will complement one

\footnotetext{
${ }^{156}$ Samuels, above n 149.

${ }^{157}$ Ibid.

158 William Fisher, Promises to Keep: Technology, Law and the Future of Entertainment (Stanford University Press, 2004).

${ }^{159}$ McLeod and DiCola, above n 16, 203-6.

${ }^{160}$ Ibid 14.

${ }^{161}$ Ibid 216.

162 Ibid.
} 
another' ${ }^{163}$ However, McLeod and DiCola do not see compulsory licensing as being a viable option in the foreseeable future - given the opposition in various quarters of the music industry. ${ }^{164}$

A further concern is that the Australian system of copyright collecting societies lacks proper regulation. At present, Australian copyright collecting societies are only subject to weak supervision by external bodies, such the AttorneyGeneral's Department, the Australian Competition and Consumer Commission, the Copyright Tribunal, and internal management and industry codes of conduct. As a result, there have been concerns about the accountability, transparency, and the monopoly power of copyright collecting societies in Australia.

The dispute in the Kookaburra case highlights the need for a transformation not only of copyright law, but also of the culture and the business of the music industry. ${ }^{165}$

\section{REMEdiEs}

The Kookaburra case also raises the larger questions about remedies in respect of copyright infringement. There has been much concern about the relationship between copyright infringement and remedies.

In his third ruling, Jacobson $\mathrm{J}$ discussed the question of remedies in the Kookaburra matter. ${ }^{166}$ The case was unusual in this respect. The action established was for damages under s 82 of the Trade Practices Act 1974 (Cth) for loss caused by contravention of s 52 of that Act, relating to misleading and deceptive conduct made to the copyright collecting societies, the Australasian Performing Right Association (APRA) and the Australasian Mechanical Copyright Owners Society. This required finding of copyright infringement. Jacobson $\mathrm{J}$ was required to determine 'the percentage interest, and any other entitlement that Larrikin may have, to APRA and AMCOS income in relation to

\footnotetext{
163 Ibid 257.

${ }^{164}$ Ibid 232.

165 Kal Raustiala and Christopher Sprigman, The Knockoff Economy: How Imitation Sparks Innovation (Oxford University Press, 2012) 232.

${ }^{166}$ Larrikin No 2 [2010] FCA 698.
} 
the exploitation of Down Under' ${ }^{167}$ David Brennan has written a piece about the restitutionary heresy of the Larrikin case. ${ }^{168}$

Adam Simpson, lawyer for Larrikin Music which owned the rights to Kookaburra, hoped for significant damages to be awarded in respect of copyright infringement: 'I mean, anything from what we've claimed which is between $\$ 40$ and $\$ 60$ [million] and what they suggest, which is considerably less'. ${ }^{169}$

The judge applied the principles applicable to an award of damages for copyright infringement as stated by Pumfrey $\mathrm{J}$ in Ludlow Music Inc $v$ Williams $(\text { No } 2)^{170}$ — the dispute involving the British pop singer, Robbie Williams. Jacobson $\mathrm{J}$ noted that the parties disagreed as to the significance of a number of factors in relation to the determination of remedies:

The principal factor is the musical significance of the two bars of Kookaburra which are reproduced in the flute riff of Down Under. Larrikin emphasises the musical and thematic significance of the bars of Kookaburra. By contrast, the respondents submit that the reference to Kookaburra, when considered objectively, is qualitatively and quantitatively an insignificant part of the relevant versions of Down Under. ${ }^{171}$

The judge also noted: 'A further issue which arises is whether the percentage figure that is payable is to be paid on all versions of Down Under regardless of whether they contain the "offending" bars of Kookaburra., ${ }^{172}$

Jacobson J considered the evidence provided by Norman Lurie for Larrikin Records: 'Lurie expressed the opinion that having regard to his experience in conducting licence negotiations in the industry, and taking into account percentages that were agreed in other instances of sampling, a fair remuneration for the licence to use the copyright in Kookaburra for the purpose of writing and exploiting Down Under negotiated on an arm's length basis between willing parties would have been a royalty in the order of between $25 \%$ and $50 \%$ of the total income of Down Under. ${ }^{173}$ The judge noted the evidence of Lurie that the reference to the Kookaburra song 'contributes significantly to the feel of the

\footnotetext{
${ }^{167}$ Ibid [6].

${ }^{168}$ David Brennan, 'The Beautiful Restitutionary Heresy of a Larrikin' (2011) 33 Sydney Law Review 209.

169 Sarah Dingle, 'Kookaburra Rip-off a "Musical Accident”', ABC News, 4 February 2010

$<$ http://www.abc.net.au/news/2010-02-04/kookaburra-rip-off-a-musical-accident/322496>.

${ }^{170}$ [2002] EWHC 638.

${ }^{171}$ Larrikin No 2 [2010] FCA 698 [10]-[14].

${ }^{172}$ Ibid [22].

${ }^{173}$ Ibid [45].
} 
song' and 'it is in itself evocative of the Australian national identity.' ${ }^{174}$ The judge also noted that Lurie's stance came under close scrutiny during crossexamination: 'Lurie also acknowledged in cross-examination that during a negotiation for a licence to sample an earlier work, the copyright owner would want to have a very clear appreciation of how the copyright work is to be used in the derivative work. ${ }^{175}$

By contrast, the copyright manager of EMI Music Publishing Australia 'took issue with some of the samples referred to by $\mathrm{Mr}$ Lurie and put forward other samples which pointed to a lower percentage licence fee'. ${ }^{176}$ Jacobson J noted: 'The effect of his affidavit was that the reference to Kookaburra in the flute riff of Down Under would justify "a couple of percent” of the royalties. Later, he explained this as $5 \%$ or less.' 177

Jacobson $\mathrm{J}$ noted the evidence of Colin Hay was hostile to the notion that Larrikin Records deserved any percentage of the income in respect of the song, Down Under: 'It is sufficient to say that Mr Hay made it plain that he would have vigorously resisted the payment of any, or any substantial share, of the income from Down Under to Larrikin.' ${ }^{178}$ The judge also considered the evidence of the producer who highlighted a range of distinctive features and motifs in Down Under - of which the flute riff was only one amongst many features of the work. The judge also looked at expert evidence from Dr Ford and Mr Armiger.

After such deliberations, Jacobson J held: 'It seems to me that taking a balanced view, the musical significance of the relevant bars from Kookaburra is relatively small'. ${ }^{179}$ First, the judge noted: 'In considering the significance of the bars from Kookaburra in Down Under we are listening to fragments of melody'. ${ }^{180}$ Jacobson J noted: 'It is not easy to detect those bars as is plain from the fact that the resemblance went unnoticed, even to Mr Lurie, for some 20 years'. ${ }^{181}$ Secondly, the judge held: 'Whilst I accept that the two bars of Kookaburra in that example of the flute riff are an essential part of an integrated musical sentence, they are a relatively small part of the musical elements which give Down Under its significant musical quality overall. ${ }^{182}$ Thirdly, the judge did

\footnotetext{
${ }^{174}$ Ibid [49].

${ }^{175}$ Ibid [72].

${ }^{176}$ Ibid [81].

${ }^{177}$ Ibid [82].

${ }^{178}$ Ibid [98]-[99].

${ }^{179}$ Ibid [136]-[137].

${ }^{180}$ Ibid [138].

${ }^{181}$ Ibid [138].

${ }^{182}$ Ibid [141].
} 
not 'consider that Mr Mclan's emphasis on the flute line as the lead solo instrument alters my view of the relatively small musical significance of Kookaburra in Down Under as a whole' ${ }^{183}$ Fourthly, Jacobson J held: 'It is plain that the lyrics, the tight structure of the verses and chorus and the "anthemic" quality of the song are critical parts of the 1981 recording., 184 Fifthly, the judge ruled: 'I accept that the 1981 recording does stand on its own, although some recognition must be given to Mr McIan's acknowledgement of the fact that the flute riff adds to the commercial appeal of the song. ${ }^{185}$ Jacobson $\mathrm{J}$ held in conclusion: 'But once it is acknowledged that the flute riff does not owe its entire existence to Kookaburra and that the similarity went unnoticed for 20 years, a balanced approach to the contribution of Kookaburra suggests that its musical significance to the whole of the 1981 recording is small., ${ }^{186}$

Considering the thematic significance of the Kookaburra song in the 1981 recording, Jacobson J commented that there 'may be considerable tension between Larrikin's emphasis on the overall Australian flavour of Down Under and its claim for a large percentage of the work' because 'Down Under employs many Australian images apart from Kookaburra'. ${ }^{187}$ The judge noted that the evidence included 'Mr Hay's explanation of the inspiration of the verses as well as the references in the lyrics to things that may be described as typically Australian such as Vegemite, the "fried out" Kombi and beer'. ${ }^{188}$ The judge commented:

There is no escape from the proposition that there are constant references to Australia throughout Down Under ... I accept that Down Under is an affectionate celebration and a witty commentary on some of the icons of Australian popular culture. But it is implicit in this, and indeed it is plain from what I have already said, that there are numerous references to other icons throughout the song. A balanced view of the contribution that the two bars of Kookaburra make to the overall theme of the 1981 recording must be seen as quite low. ${ }^{189}$

In conclusion, Jacobson $\mathrm{J}$ held: 'Whether the hypothetical bargain is assessed at 1982 or 2002, the percentage interest payable is at the lowest end of the spectrum. ${ }^{190}$ The judge ruled: 'Upon a proper consideration of all the relevant

\footnotetext{
${ }^{183}$ Ibid [143].

${ }^{184}$ Ibid [149].

185 Ibid [152].

${ }^{186}$ Ibid [153].

${ }^{187}$ Ibid [158].

${ }^{188}$ Ibid [159].

${ }^{189}$ Ibid [162]-[163].

${ }^{190}$ Ibid [214].
} 
factors there is nothing to suggest that the owner of the copyright in Kookaburra would have had substantial bargaining power. ${ }^{191}$ Jacobson J observed: 'The most obvious factor is the difficulty in detecting the similarity between the flute riff and the bars from Kookaburra.' 192 The judge ruled: 'A further strong indicator of a low percentage is to be found in a qualitative and quantitative consideration of Kookaburra's contribution to Down Under, looked at a whole.' 193 Jacobson J noted: 'Whilst it is true that the commercial success of Down Under in 2002 may have given the copyright owner of Kookaburra an opportunity to capitalise upon its statutory monopoly, that is outweighed by the other factors to which I have referred'. ${ }^{194}$ The judge held: 'Taking the most generous approach that is open to me having regard to the figures put to me by the parties, I estimate the figure at $5 \%$ whether the percentage is determined in 1982 or 2002. ${ }^{, 195}$ Jacobson observed that 'the $5 \%$ figure is the total percentage payable to Larrikin of the APRA/AMCOS income' and that 'common sense would suggest the application of the $5 \%$ figure to future payments. ${ }^{, 196}$ In a sharp rebuke to Larrikin's demands, Jacobson J ruled: 'I consider the figures put forward by Larrikin to be excessive, overreaching and unrealistic. ${ }^{, 197}$

In his judgment on appeal, Emmett J commented: 'Of course, the significance of the anomalous operation of the Copyright Act can be addressed in terms of the remedies and relief granted in respect of infringement' ${ }^{198}$ It is certainly true that the judge at first instance took into account the circumstances of the case in the determination of remedies. Another possible solution to the Kookaburra case would have been for the Federal Court of Australia to award a peppercorn rent. Such a position would have reflected an interpretation of the dispute consistent with that of Colin Hay.

Australian courts have certainly been creative in the use of their discretion in respect of remedies in the past. In the 1990s, von Doussa J was creative in his use of remedies to deal with the infringement of Indigenous intellectual property. In the Carpets case, he recognised a collective award of damages. ${ }^{199}$ In the Bulun Bulun case, the judge recognised that, in exceptional

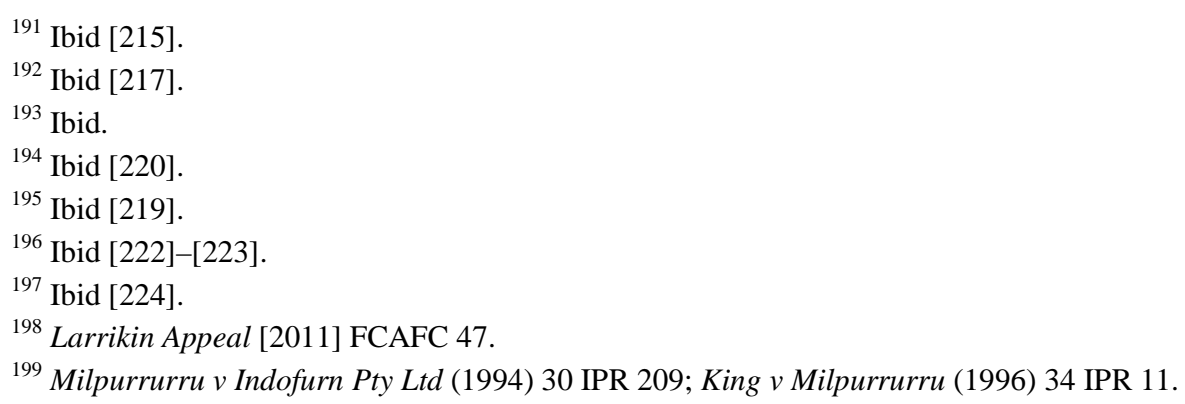


circumstances, an Indigenous community could bring an action for copyright infringement. $^{200}$

In a 2006 piece, Professor Timothy Wu of Columbia Law School, and author of The Master Switch, ${ }^{201}$ discussed the problem of musical sampling trolls under United States copyright law:

Similar to its cousins the patent trolls, Bridgeport and companies like it hold portfolios of old rights (sometimes accumulated in dubious fashion) and use lawsuits to extort money from successful music artists for routine sampling, no matter how minimal or unnoticeable. The sample trolls have already leveraged their position into millions in settlements and court damages, but that's not the real problem. The trolls are turning copyright into the foe rather than the friend of musical innovation. ${ }^{202}$

Wu observes that '[c]opyright is supposed to be the servant of artists, but today that is all too often just a pretense'. ${ }^{203}$ He comments: 'The vast majority of the nation's valuable copyrights are owned not by creators, but by stockpilers of one kind or another, and Bridgeport is just a particularly pernicious example'. ${ }^{204}$ $\mathrm{Wu}$ argues that there is a need for copyright law reform to deal with the problem of sampling trolls and says '[w]e need better devices to keep the control of the most valuable of artist's rights with artists'. ${ }^{205}$ He concludes '[f]or, to paraphrase Judge Learned Hand, copyright was born to protect and liberate musicians, but it all too often ends up enslaving them'. ${ }^{206}$

In the United States, the EFF has been particularly concerned about the problem of copyright trolls in a number of contexts. ${ }^{207}$ The EFF has been 'working hard to help victims get access to the resources they need to defend their rights call the court's attention to trolls' disrespect for due process and educate the public about the harms of copyright trolling'. ${ }^{208}$ First, the EFF was concerned about the litigation campaign by the Recording Industry Association of America against individual music fans who used peer-to-peer networks to share music. Secondly, the EFF has been concerned about the practices US Copyright Group, which has

\footnotetext{
${ }^{200}$ Bulun Bulun v R \& T Textiles Pty Ltd (1998) 41 IPR 513.

${ }^{201}$ Timothy Wu, The Master Switch: The Rise and Fall of Information Empires (Vintage, 2011).

202 Timothy Wu, 'Jay-Z Versus the Sample Troll: The Shady One-Man Corporation that's Destroying Hip-Hop', Slate Magazine (online), 16 November 2006 $<$ http://www.slate.com/articles/arts/culturebox/2006/11/jayz_versus_the_sample_troll.html>. 
represented the producers of several films including The Hurt Locker and Far Cry. The civil society group complains: 'USCG then files predatory lawsuits implicating thousands of unnamed John Does, subpoenas their identities from the ISPs, and then sues the individuals themselves. ${ }^{209}$ Thirdly, the EFF has been worried about the activities of Righthaven LLC, which has brought a large number of lawsuits in a Nevada federal court claiming copyright infringement in respect of newspaper stories. United States courts questioned whether Righthaven LLC was entitled to bring such legal action. Righthaven LLC has since become a defunct entity. ${ }^{210}$ Fourthly, the EFF has been concerned about copyright owners of adult pornographic movies filing mass lawsuits for copyright infringement. The EFF observed: 'The judge in several of the cases filed in West Virginia has blocked plaintiffs from proceeding against almost all of the defendants in those cases - approximately 5,400 people. ${ }^{, 211}$

The United States courts have sought to address concerns about patent trolls and copyright trolls. The Supreme Court of the United States handed down an important precedent in the matter of eBay $v$ MercExchange. ${ }^{212}$ Thomas $\mathrm{J}$ emphasised:

According to well-established principles of equity, a plaintiff seeking a permanent injunction must satisfy a four-factor test before a court may grant such relief. A plaintiff must demonstrate: (1) that it has suffered an irreparable injury; (2) that remedies available at law, such as monetary damages, are inadequate to compensate for that injury; (3) that, considering the balance of hardships between the plaintiff and defendant, a remedy in equity is warranted; and (4) that the public interest would not be disserved by a permanent injunction. ${ }^{213}$

The ruling has been extended from the field of patent law to the discipline of copyright law. In the 2011 case of Perfect $10 v$ Google, ${ }^{214}$ the Court of Appeals for the Ninth Circuit applied the eBay ruling on remedies to a copyright situation. Ikuta J held: 'We therefore conclude that the propriety of injunctive relief in cases arising under the Copyright Act must be evaluated on a case-bycase basis in accord with traditional equitable principles and without the aid of presumptions or a "thumb on the scale" in favour [sic] of issuing such relief. ${ }^{215}$

\footnotetext{
${ }^{209}$ Ibid.

${ }^{210}$ David Kravets, 'Defunct Copyright Troll Seeks Resurrection', Wired (online), 3 July 2012 $<$ http://www.wired.com/threatlevel/2012/07/righthaven-second-life/>.

${ }^{211} \mathrm{EFF}$, above $\mathrm{n} 207$.

${ }^{212} 547$ US 388 (2006).

${ }^{213}$ Ibid 390.

${ }^{214} 653$ F 3d 976 ( $9^{\text {th }}$ Cir, 2011).

${ }^{215}$ Ibid.
} 
The Washington Declaration on Intellectual Property and the Public Interest 2011 has emphasised the need to check the excesses of intellectual property enforcement. ${ }^{216}$ It has noted: 'The maximalist intellectual property agenda includes a push at all levels for stronger enforcement - in courts, on the street, at borders, and now on the Internet. ${ }^{, 217}$ The Declaration stressed the need to 'ensure that legal penalties, processes, and remedies are reasonable and proportional to the acts of infringement they target' ${ }^{218}$ It warned of the need to 'ensure that public authorities retain and exercise rigorous oversight of critical enforcement functions, including policing, criminal enforcement and ultimate legal judgments. ${ }^{219}$

\section{CONCLUSION: THE SONG OF THE LYREBIRD}

The Kookaburra case is a tragedy. The decision represents a failure of the discipline of copyright law, and should be a spur for reform. The ruling is an injustice and there were no victors. Men at Work were devastated by the ruling of copyright infringement; EMI was vanquished, and its judgment called into question. Although Larrikin Records may have won the litigation, the reputation of the company was traduced in the media and the court of public opinion. The very credibility and legitimacy of copyright law as an institution and as a discipline was called into question. Colin Hay has said that the ruling could restrict musical creativity: 'It all comes from somewhere else, so that's why you must have in this musical environment a robust creative domain in which to create. I think more than anything else, it's going to be interesting for the future whether further litigious cases are going to come up after this precedent has been set. ${ }^{, 220}$ Just as Men at Work was an international band whose music spoke to people far and wide, the Kookaburra case has a wider resonance for international debates over copyright law and musical works. As a precedent, the case will be particularly worrisome for practitioners of digital sampling, ${ }^{221}$ DJ remixing, ${ }^{222}$ and mash-ups. ${ }^{223}$ The tragedy of the Kookaburra case has

\footnotetext{
216 The Global Congress on Intellectual Property and the Public Interest, The Washington

Declaration on Intellectual Property and the Public Interest (2011) $<$ http://infojustice.org/washington-declaration-html $>$.

${ }^{217}$ Ibid.

${ }^{218}$ Ibid.

${ }^{219}$ Ibid.

${ }^{220}$ Dingle, above $n 169$.

${ }^{221}$ Franzen and McLeod, above n 16; McLeod and DiCola, above n 16.

${ }^{222}$ Gaylor, above n 18.

${ }^{223}$ Sam Howard-Spink, 'Grey Tuesday, Online Cultural Activism and the Mash-Up of Music and Politics' (2004) 9(10) First $<$ http://www.firstmonday.org/issues/issue9_10/howard/index.html>; Michael Allyn Pote,
} 
highlighted the need for substantive copyright law reform in Australia in a number of areas relating to copyright infringement, copyright exceptions, and remedies for copyright infringement.

In his appeal judgment, Emmett $\mathrm{J}$ also wondered about the long duration of copyright protection in the Kookaburra case: 'While there are good policy reasons for encouraging the intellectual and artistic effort that produces literary, artistic and musical works, by rewarding the author or composer with some form of monopoly in relation to his or her work, it may be that the extent of that monopoly, both in terms of time and extent of restriction, ought not necessarily be the same for every work. ${ }^{, 24}$ In these remarks, Emmett J aired a deep, abiding concern that the term of copyright protection is excessively long, especially when compared to a registration scheme like patent law (which merely provides a duration of protection for 20 years, or up to 25 years for pharmaceutical drugs). ${ }^{225}$ If the excessive length of the copyright term cannot be fixed, there is a need to make other ameliorating reforms to copyright law. One constructive measure would be for the age of a copyright work to be taken into account into determinations of copyright subsistence, copyright infringement, copyright exceptions, and copyright remedies.

The funeral for Greg Ham was marked by a number of tributes to the Men at Work multi-instrumentalist. Ham's ex-wife, Linda 'Toots' Wostry, said her partner of 19 years (and long-time friend) struggled with depression and anxiety following a court's finding in 2010 that his signature flute riff in Down Under infringed copyright in the musical work of the Kookaburra song. She said that '[t]he decision, along with the case's associated costs, took their toll on his health'. ${ }^{226}$ Wostry commented: 'I personally couldn't fathom how playing a fragment of a melody in a jazz context, known as "quoting", is considered the height of musical wit, while in a rock context, it becomes plagiarism' ${ }^{227}$ She wondered whether '[p]erhaps it has something to do with perceiving revenue to be had' ${ }^{228}$ Colin Hay described Greg Ham as 'a beautiful man'. 'We played in a band and conquered the world together. I love him very much. ${ }^{, 29}$ Long-time

\footnotetext{
'Mashed-Up in Between: The Delicate Balance of Artists' Interests Lost Amidst the War on Copyright' (2010) 88 North Carolina Law Review 639.

${ }^{224}$ Larrikin Appeal [2011] FCAFC 47, above n 13 [100].

225 There has nonetheless been much concern about direct and indirect efforts to extend the duration of patents in Australia. See, eg Robert Chalmers, 'Evergreen or Deciduous? Australian Trends in Relation to the "Evergreening” of Patents' (2006) 30 Melbourne University Law Review 29.

${ }^{226}$ AAP, 'Men at Work’s Greg Ham Farewelled', The Herald Sun (Melbourne), 2 May 2012.

${ }^{227}$ Ibid.

${ }^{228}$ Ibid.

${ }^{229}$ Kylie Northover and Chris Johnston, 'How the Song Turned Sour for a Beautiful Man', The Age (Melbourne), 19 April 2012.
} 
friend Kelvin McQueen read a poignant poem which praised Ham's character and told how his musical prowess had touched millions of lives: 'The music you played has stayed deep in our psyche, deep in our brain, ever to remain. ${ }^{230}$

In an eloquent opinion, the storyteller Anson Cameron expressed his dismay over the litigation. ${ }^{231}$ He reflected: 'When Larrikin Music sued Men At Work, claiming Down Under was a rip-off of Kookaburra, it seemed a brutal act to me ... [t]o sue songwriters over copyright of a song that had lived large for 30 years. ${ }^{232} \mathrm{He}$ commented that much artistic creation is based upon imitation and mimicry and homage:

It's important, before calling an artist a thief, to ask what theft is. All artists begin in imitation. Every Jimi wannabe who sits down to take a guitar lesson commits a small theft. Shakespeare stole scenes straight from Plutarch. A very few gifted, driven souls make it out into fresh territory. ${ }^{233}$

In his lively literary collection, Pepsi Bears, ${ }^{234}$ Anson Cameron created a fictional shadow text about the dispute over copyright law and musical works as a 'salute to the musicians'. ${ }^{235}$ The work is entitled 'Song of the Lyrebird'. It is about a legal action by the copyright owner of Ulladulla Lullaby against an Australian rock anthem called Because of $\mathrm{Oz}$. The short story contains some gentle satire about the role of lawyers, judges, and the law in managing cultural disputes. Instead of being hounded by lawyers like Men at Work, the Jejubes became celebrated heroes: 'What right-thinking young person didn't want to see this sort of justice served up under Blue Skies?' ${ }^{236}$ The short story considers the question of whether mimicry is natural or artificial, lawful or unlawful, fair or not. The short story finishes: 'For nature is the most adept plagiarist never to be accused of the crime, and knows a pretty tune when she hears one. ${ }^{237}$

\footnotetext{
${ }^{230}$ Ibid.

${ }^{231}$ Anson Cameron, ‘To Quote BB King: I Don’t Think Anybody Steals, All of Us Borrow', The Sydney Morning Herald (Sydney), 22 April 2012.

${ }^{232}$ Ibid.

${ }^{233}$ Ibid.

${ }^{234}$ Anson Cameron, Pepsi Bears and Other Stories (Vintage Books, 2011).

${ }^{235}$ Cameron, above n 231.

${ }^{236}$ Cameron, above n 234, 220, 'Song of the Lyrebird'.

${ }^{237}$ Ibid 223.
} 